\section{Adaptability, stability, and genetic divergence of conilon coffee in Alto Suaçuí, Minas Gerais, Brazil}

\section{Vânia Aparecida Silva ${ }^{1^{*}}$, Janaine Lopes Machado², Juliana Costa de Rezende ${ }^{1}$, Alexandrino Lopes de Oliveira ${ }^{3}$, Ulisses José de Fi- gueiredo ${ }^{4}$, Gladyston Rodrigues Carvalho ${ }^{1}$, Maria Amélia Gava Ferrão ${ }^{5}$ and Rubens José Guimarães ${ }^{2}$}

\begin{abstract}
The objective of this study was to describe the genetic parameters, adaptability, and stability of clones from the Coffea canephora variety 'Vitória Incaper 8142', and the genetic divergence between them. Following 12 and 24 months of plant growth, several traits were evaluated, including stem diameter, plant height, canopy diameter, number of plagiotropic branches, and number of nodes per plagiotropic branch. The agronomic performance of four crops was determined using measurements of productivity, yield, percentage of floating grains, and grade of the beans. Variability was observed between the clones for the majority of the traits measured. The clones V7, V10, V12, and V13 were the most stable and displayed the highest degree of adaptation for the studied traits, and thus these clones will be used to establish a base population suited to the growing conditions in Alto Suaçuí, Minas Gerais, Brazil. Additionally, the genetic dissimilarity identified between clones allowed suitable clone combinations to be proposed for use in future crosses.
\end{abstract}

Key words: Coffea canephora, mixed models, clones, MHPRVG method, genetic dissimilarity.

\section{INTRODUCTION}

The territory of Alto Suaçuí Grande in the state of Minas Gerais is included in the territorial model created by the Ministry of Agrarian Development, which aims to combat poverty, reduce social inequalities, promote productive inclusion, and strengthen family farming. Within the guidelines established for the region, the introduction of conilon coffee to the area was identified as an option to promote sustainable development of the territory. However, the state of Minas Gerais traditionally produces arabica coffee, and therefore little is currently understood concerning the cultivation of conilon coffee in the region (Silva et al. 2015).

Conilon coffee is an alternative coffee crop in the region because of its rustic qualities, meaning that it is able to adapt to tropical edaphoclimatic conditions of low altitude and high temperatures, and it also exhibits enhanced drought tolerance. 'Vitória Incaper 8142 ' is one of the conilon varieties that possesses these traits, and was developed by the Instituto Capixaba de Pesquisa, Assistência Técnica e Extensão Rural (INCAPER/ES) by a process
Crop Breeding and Applied Biotechnology 17: 25-31, 2017 Brazilian Society of Plant Breeding. Printed in Brazil http://dx.doi.org/10.1590/198470332017v17n1a4

\footnotetext{
*Corresponding author: E-mail: vania.silva@epamig.ufla.br
}

Received: 30 October 2015 Accepted: 22 September 2016

${ }^{1}$ Empresa de Pesquisa Agropecuária de Minas Gerais (EPAMIG), Unidade Sul, Campus da Universidade Federal de Lavras (UFLA), CP 176, 37.200-000, Lavras, MG, Brazil 2 UFLA, Departamento de Agricultura, CP 3037, 37.200-000, Lavras, MG, Brazil ${ }^{3}$ Centro Universitário do Planalto de Araxá (UNIARAXÁ), Av. Min. Olavo Drummond, 05, São Geraldo, 38.180-129, Araxá, MG, Brazil

${ }^{4}$ Barenbrug do Brasil Sementes Ltda, Rodovia SP 345, km 131, s/n, CP 07, 14.790-000,

Guaíra, SP, Brazil

${ }^{5}$ Embrapa Café/Incaper, Rua Afonso Sarlo, 160, Bairro Bento Ferreira, 29.052-010, Vitória, ES, Brazil 


\section{VA Silva et al.}

whereby elite clones that display genetic heterogeneity whilst maintaining compatibility with each other were bred (Contarato et al. 2014).

Statistical studies of different quantitative traits, which are governed by many genes and are greatly influenced by the environment (Barili et al. 2015), are required to enable variety identification and also to select clones for use in a breeding program focused on developing varieties suited to the region. In order to reliably identify varieties and clones, selection methods must be rigorous and accurate, repeated assessments must be performed for each clone over time, and special methods must be developed to estimate genetic parameters and genetic/phenotypic prediction values (Carias et al. 2014, Silva et al. 2015). The mixed models methodology is a statistical approach that enables accurate prediction and is not skewed by genetic values, even in unbalanced situations. It also facilitates the simultaneous use of clonal information and repeated measurements over time, which enables precise identification and selection of varieties and promising clones (Henderson 1984).

With the use of various measures in the same individual, interaction effects of genotypes and crops may be present, and thus behavior of the clones is not consistent over successive characterizations or harvests. To circumvent these interaction effects, the methodology of the harmonic mean of the relative performance of the genetic values (MHPRVG) is used for studies of adaptability and stability (Resende 2007a). The main advantages of this approach, which has already been applied to conilon coffee (Carias et al. 2014), include the fact that that genotypic effects are considered as random - therefore providing genotypic stability whilst allowing for phenotypic variation - and allowing a degree of unbalance, meaning a heterogeneity of variances (Resende 2007a).

Thus, the objective of this study was to describe the genetic parameters of clones of Coffea canephora variety 'Vitória Incaper 8142 ' and to verify their adaptability and stability to form a base population in the Alto Suaçuí Grande region. Simultaneously, this study aimed to provide the most divergent clones to be used in intrapopulational crossing in order to exploit the greater genetic variability that exists within segregating populations.

\section{MATERIAL AND METHODS}

The experiment was established in January 2009 on private property in Água Boa (lat $17^{\circ} 59^{\prime} \mathrm{S}$, long $42^{\circ} 23^{\prime} \mathrm{W}$ and alt $415 \mathrm{~m}$ asl), located in the territory of Alto Suaçuí Grande, Minas Gerais. The area has an Aw climate, characterized as hot, tending to semi-arid, with rainfall occurring between January and March and then drought conditions for the remainder of the year. The average annual temperature is $22^{\circ} \mathrm{C}$ and the soil found in the experimental area is Oxisol.

Thirteen clones of the variety 'Vitória Incaper 8142', produced in the INCAPER/ES C. canephora breeding program, were evaluated in a randomized block design with four replicates and six plants per plot. Plot spacing was $3.0 \times 1.0 \mathrm{~m}$ and the experiment was initiated with seedlings. Plant sowing and care were performed in accordance with the technical recommendations for the culture of species (Ferrão et al. 2007).

Following 12 and 24 months of growth, several traits were evaluated including stem diameter (SD), measured using a pachymeter $(\mathrm{cm})$; plant height $(\mathrm{H})$, measured from the base of the stem (ground surface) to the shoot apex (cm); canopy diameter $(C D)$, which measured the reach of the largest branch $(\mathrm{cm})$ in a transverse direction to the planting line; and both the number of plagiotropic branches (NPB) and the number of nodes per plagiotropic branch (NN), measured by counting those present in four alternating branches.

Measurements of agronomic traits were performed for the four crops 2010/2011, 2011/2012, 2012/2013, and $2013 / 2014$. These traits included productivity (PROD), yield (YIELD), percentage of floating grains (\% FG), and grade of the beans using sieve techniques (\% S10 and \% S15-13). PROD was assessed by determining the number of 60-kg bags of hulled coffee produced per hectare (bags ha-1). The harvest was carried out in individual plots and the volume of field coffee (coffee fruits of mixed maturity) per plot was recorded. Subsequently, the volume of harvested coffee was converted to bags ha-1 ${ }^{-1}$ considering the yield. This determination was performed by collecting a representative sample of field coffee produced in each plot and drying and processing the beans. Fruits were sampled from plants in each plot (500 $\mathrm{mL}$ per plot) from plagiotropic branches located in four quadrants for determining \% FL, according to the methodology described by Antunes Filho and Carvalho (1954). The coffee produced was graded using sieve techniques, to determine bean quality. This analysis was performed by qualified professionals from Empresa de Pesquisa Agropecuária de Minas 
Gerais - EPAMIG, according to Normative Instruction № 08 (Mapa 2003), and bean grade was determined by calculating the percentage of grain retained in sieve 10 (\% S10) and in sieve 15 and 13 combined (\% S15-13).

Analyses were performed for all crops in conjunction. The variance components and the prediction of random effects were estimated using the REML/BLUP procedure (maximum likelihood restricted/best linear prediction not biased) (Resende 2007a).

For this, the following statistical model was used

$y=X m+Z c+W p+T i+e$

wherein:

$y$ : vector of data; $m$ : vector of combined effects of crop-replicates (fixed) added to the overall average; $c$ : vector of genotypic effects of the clones (random), where $c \sim N M V\left(0, I \sigma_{c}^{2}\right)$. The $\sigma_{c}^{2}$ is the genotypic variance associated with clone effects; $p$ : vector of permanent environmental effects (random), where $p \sim N M V\left(0, I \sigma_{p}^{2}\right)$. The $\sigma_{p}^{2}$ is variance associated with plot effects; $i$ : vector of clone interaction effects $\times$ crops (random), where $i \sim N M V\left(0, I \sigma_{c s}^{2}\right)$. The $\sigma_{c s}^{2}$ is variance component associated with clone interaction effects $\times$ crops; e: random vector error, where $e \sim N M V\left(0, I \sigma_{e}^{2}\right) ; X, Z, W$ and $T$ : incidence matrixes for $m, c, p$ and $i$, respectively.

The Likelihood Ratio Tests (LRT) was used to estimate the average heritability of clones $\left(h_{m}^{2}\right)$, genetic correlations of the genotypes across the crops $\left(r_{g}\right)$, and the accuracy. LRT was also used to test the significance of the random effects such as genetic variance among clones $\left(\sigma_{c}^{2}\right)$ and the variance of the clone interaction effects $\times$ crops $\left(\sigma_{c s}^{2}\right)$, whereby deviance analysis was obtained for each trait (Resende 2007a).

From the predicted genotype values, the gains with selection (GS) were estimated with a selection intensity of $30 \%$ (4 clones) using the expression

$G S=-\left(\frac{M s-M o}{M o}\right) \times 100$

wherein:

GS: the gain obtained with the selection, in a percentage value; Ms: clone average for the desired trait, selected from the desired selection intensity; Mo: initial clone average for each desired trait before selection.

Selection was carried out based on productivity, adaptability, and stability of the clones using the statistical method MHPRVG (Resende 2007a). These statistical analyses were performed using the SELEGEN-REML/BLUP software (Resende 2007b, 2016).

To estimate the genetic divergence, the values predicted for each genotype within each group were used to estimate the matrix of genetic Mahalanobis distances and, for group delimitation, the hierarchical method UPGMA (Unweighted Pair-Group Method Using Arithmetic Averages) was applied using the Genes computational applicative software (Cruz 2013).

\section{RESULTS AND DISCUSSION}

The variance components, genetic parameters, and phenotypes estimated for the evaluated traits (Table 1) have averages and variances consistent with other studies analyzing conilon coffee progenies (Ferrão et al. 2008, Rodrigues et al. 2012). Considering the evaluated traits, genotypic variance was significant for the traits NPB, CD, \% FG, \% S10, and \% S15-13 between the clones, according to the LRT at a 5\% significance level (Table 1). The existence of variability in C. canephora, a necessary quality for the selection of superior genotypes in a breeding program (Mistro et al. 2007, Teixeira et al. 2013), has been verified in past studies (Cecon et al. 2008, Mistro et al. 2008). The variability within $C$. canephora can be attributed to its field origin, open pollination, and association with self-incompatibility.

Estimates of genotypic correlation coefficients amongst the crops, according to the classification of Resende (2007a), were high, ranging from 70 to $99 \%$ for most of the evaluated traits (H, NPB, CD, \% S10, \% S15-13), which indicates a simple interaction between crops. These results indicate that, except for the traits PROD, YIELD, and \% FG where a complex interaction is expected, clone ranking is not expected to change significantly between crops, which allows for selection 
Table 1. Evaluation of 13 clones of the 'Vitória Incaper 8142' conilon coffee variety in four crops at Surubim Farm in Água Boa-MG. Estimates of genetic parameters regarding the traits stem diameter $(\mathrm{SD}, \mathrm{cm})$, plant height $(\mathrm{H}, \mathrm{cm})$, number of plagiotropic branches (NPB), canopy diameter (CD, cm), number of nodes per plagiotropic branches (NN), productivity (PROD, bags ha-1), yield (YIELD), percentage of floating grains (\% FG), grain retained in sieve 10 (\% S10), and grain retained in sieve 15 and 13 combined (\% S15-13)

\begin{tabular}{|c|c|c|c|c|c|c|c|c|c|c|}
\hline $\mathbf{P}^{1}$ & SD & $\mathbf{H}$ & NPB & CD & NN & PROD & YIELD & $\%$ FG & $\%$ S10 & \% S15-13 \\
\hline$\sigma_{c}^{2}$ & 0.20 & 43.75 & 4.48 & 32.31 & 5.01 & 91.76 & 1.62 & 32.42 & 27.33 & 77.8317 \\
\hline $\mathrm{LRT}^{2}$ & 0.01 & 3.28 & $7.49 *$ & $4.43^{*}$ & 0.01 & 3.48 & 0.26 & $6.33^{*}$ & $10.93^{*}$ & $13.58^{*}$ \\
\hline$\sigma_{c s}^{2}$ & 4.30 & 0.74 & 0.04 & 0.57 & 164.95 & 142.68 & 10.69 & 48.32 & 12.40 & 29.4805 \\
\hline $\mathrm{LRT}^{3}$ & 1.86 & 0.00 & 0.01 & 0.00 & $9.78^{*}$ & $12.79 *$ & $15.32 *$ & $41.58^{*}$ & $9.64^{*}$ & $9.47^{*}$ \\
\hline$r_{g}$ & 4.47 & 98.34 & 99.00 & 98.28 & 2.95 & 39.14 & 13.16 & 40.16 & 69.78 & 72.53 \\
\hline$h_{m c}^{2}$ & 3.87 & 56.09 & 69.91 & 61.31 & 4.00 & 57.54 & 22.42 & 67.22 & 80.38 & 83.33 \\
\hline
\end{tabular}

${ }^{1}$ Parameters: $\sigma_{c}^{2}$ : genotypic variance, $\sigma_{c s}^{2}$ : variance of the clone interaction $\times$ crops, $r_{g}$ : genotypic correlation by means of crops $h_{m c}^{2}:$ average clone heritability, and $A C_{g e n}$ : accuracy. ${ }^{2}$ Likelihood Ratio Test (LRT) with a distribution of 1 degree of freedom for the genotypic variance. ${ }^{3}$ LRT with a distribution of 1 degree of freedom for the variance of clone interaction $\times$ crops.

* Significance, determined by $\chi^{2}$ test, at $5 \%$ probability.

work to be performed by breeders (Resende 2007a). For the vegetative traits, the variance of clone interaction $\times$ crops was significant $(P<0.05)$ for $\mathrm{NN}$ alone.

The heritability in clone average $\left(h_{m c}^{2}\right)$ for traits with significant clone effects ranged from $61 \%$ (CD) to $88.3 \%$ (\% 15 13). These parameters indicate that the experiment was conducted appropriately and the predicted genetic values were fairly accurate, thus demonstrating the ability to easily apply selection using these features. For productivity, variance presented with a heritability of $57.54 \%$, which is considered to be high because of the quantitative nature of this trait.

Likewise, the accuracy of selection was high (74.89 to $91.28 \%$ ) for almost all traits, suggesting reliable genetic progress among clones in response to selection (Resende and Duarte 2007). This suggests that selection of the best clones will enable a significant increase in the genetic value of the population concerning the majority of studied traits, aside from YIELD, SD, and NN for which the accuracy of selection was medium to low.

The predicted genotypic values were estimated in order to identify optimal clones of the analyzed variety. Based on estimates of variance (Table 1), the traits chosen for the selection of clones were \% S15-13, NPB, and PROD, as these traits were found to possess significant genetic variance (Table 2). Bean grade is a trait of great importance in $C$. canephora breeding according to Ferrão et al. (2008), because countries that import this product demand increasingly higher quality and larger grains. A significant positive correlation exists between the number of plagiotropic branches and productivity (Martinez et al. 2007, Carvalho et al. 2010), and the inclusion of productivity analysis in this study was because this is the main selection criterion for coffee trees (Gichimu and Omondi 2010, Cilas et al. 2011).

For PROD, the clones V10, V9, V7, and V12 were superior with GS of 20.99\% (Table 2). It is noteworthy that our breeding program attempts to identify genotypes that are suitable for the growing conditions in the state of Minas Gerais. Past studies indicate an average conilon coffee productivity of 35.02 bags ha $^{-1}$ in the state of Espírito Santo (CONAB 2014). In this study, we obtained an average productivity of 50.25 bags ha $^{-1}$. Considering the gain following selection of approximately $20.99 \%$, an increase in productivity of 8.72 bags ha $^{-1}$ would result from selection of the best clones within this variety.

For \% S15-13, the clones V12, V11, V4, and V13 had a higher percentage of grains in this grade, with GS of $11.91 \%$. For the growth trait NPB, the clones V1, V7, V8, and V13 had higher predicted genotypic values. The gain following selection was satisfactory, from $6.11 \%$ in selection of $30 \%$ of the clones. Once clone interaction $\times$ crops has been identified, the MHPRVG method can be applied to identify the most suitable clones that are stable between successive crops, which allows simultaneous selection for productivity, stability, and adaptability (Resende 2007a). This process forms part of the selection criteria for eucalyptus clones to build improved populations and must be used for recommended genetic material for commercial plantations (Rosado et al. 2012). For coffee trees, this method was applied and proved to be useful in the identification of appropriate C. canephora clones over four successive crops (Carias et al. 2014). 
Among the four selected clones, none performed well in all of the three selected traits combined. However, clones V7, V12, and V13 performed well in two traits, meaning that they were more adapted and stable for these traits. For productivity, the clone V10 had high MHPRVG values, meaning this clone was considered stable and was expected to result in minimal interactions within the crop, indicating uniformity in its performance during successive evaluations (Negreiros et al. 2014). Thus, the clones V7, V10, V12, and V13 were the most promising regarding the traits studied.

Considering the possibility of using these clones as potential breeding stock, crossing between clones of the variety 'Vitória Incaper 8142' may be a good strategy to generate a segregating population for the region. This is important because, in addition to the observed variability, genetic divergence between groups promotes the formation of novel varieties (Cecon et al. 2008) and potential heterosis in the offspring for traits that exhibit allelic dominance (Resende 2007a). Thus, for the evaluated traits, intrapopulational crosses between the most unique genotypes of each group would promote greater genetic variability in the progeny compared to that in the original population.

Table 2. Evaluation of 13 clones of the 'Vitória Incaper 8142' conilon coffee variety in four crops at Surubim Farm in Água Boa-MG. Estimates of genotypic values (ûtâ), overall average $\left(\overline{X_{\text {general }}}\right)$, average selected $\left(\overline{X_{\text {sel }}}\right)$, gain with selection (GS), harmonic mean of the relative performance of the genetic values (MHPRVG) for productivity traits (PROD), percentage of grain retained in sieve 15 and 13 (\% S15-13), and number of plagiotropic branches (NPB)

\begin{tabular}{|c|c|c|c|c|c|c|}
\hline \multirow[b]{2}{*}{ Clones } & \multicolumn{3}{|c|}{ (û+â) } & \multicolumn{3}{|c|}{ MHPRVG } \\
\hline & PROD & S15-13 & NPB & PROD & S15-13 & NPB \\
\hline V1 & 42.55 & 70.48 & 26.04 & 39.01 & 70.23 & 26.09 \\
\hline V2 & 39.15 & 70.47 & 25.48 & 37.67 & 70.45 & 25.50 \\
\hline V3 & 36.29 & 55.88 & 24.38 & 25.96 & 53.58 & 24.36 \\
\hline V4 & 35.21 & 75.72 & 23.03 & 31.69 & 76.35 & 22.96 \\
\hline V5 & 30.92 & 62.82 & 20.25 & 26.53 & 61.78 & 20.04 \\
\hline V8 & 34.87 & 70.90 & 26.07 & 24.52 & 71.07 & 26.12 \\
\hline V9 & 53.44 & 67.82 & 24.29 & 59.27 & 67.25 & 24.27 \\
\hline V10 & 54.55 & 73.40 & 24.11 & 64.12 & 74.19 & 24.08 \\
\hline V11 & 37.14 & 80.01 & 24.99 & 36.76 & 81.61 & 24.98 \\
\hline V12 & 44.02 & 83.06 & 25.62 & 44.59 & 85.06 & 25.64 \\
\hline GS (\%) & 20.99 & 11.91 & 6.11 & & & \\
\hline
\end{tabular}

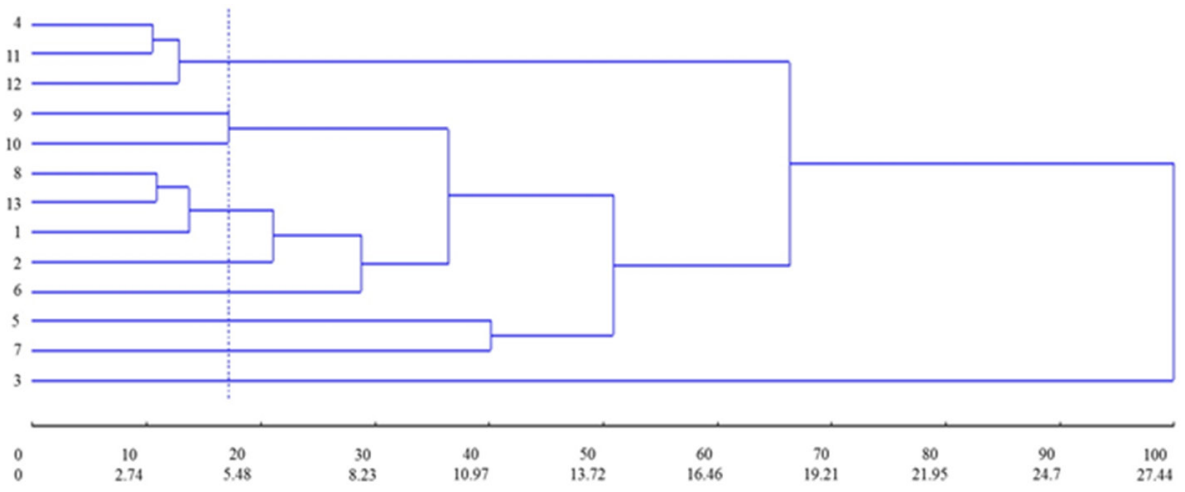

Figure 1. Representative dendrogram of genetic dissimilarity among 13 clones as determined with the UPGMA technique, using Mahalanobis generalized distance as a measure of dissimilarity. 


\section{VA Silva et al.}

The UPGMA method was applied in order to group of clones according to their genetic dissimilarity, as depicted in the dendrogram in Figure 1. A minimal limit of $18 \%$ similarity between clones resulted in the formation of nine groups for the 13 evaluated clones.

The first group consisted of the clones $\mathrm{V} 4, \mathrm{~V} 11$, and $\mathrm{V} 12$, and the fourth group consisted of the clones $\mathrm{V} 8, \mathrm{~V} 13$, and $\mathrm{V} 1$. The remaining clones ( V9, V10, V2, V6, V5, V7, and V3) remained isolated, which indicated their significant uniqueness. Likewise, Ivoglo et al. (2008) and Guedes et al. (2013) also observed the formation of distinct groups when they applied the UPGMA method in conilon and arabica coffee, respectively,

The results of this study made it possible to identify the main intrapopulational crosses that should be performed for greater genetic variability, namely V7 × V10; V7 × V12; V7 × V13; V10 $\times \mathrm{V} 12 ; \mathrm{V} 10 \times \mathrm{V} 13$; and V12 $\times \mathrm{V} 13$, which should increase the probability of obtaining superior individuals in the offspring.

\section{CONCLUSIONS}

Studies of adaptability and stability associated with the predicted genotypic values allowed the identification of clones suitable for the region of Alto Suaçuí Grande. The clones V7, V10, V12, and V13 were the most promising for the analyzed traits. These clones will be used to form a base population suited to the growing conditions in the region. The genetic variability that resulted in the formation of distinct groups following genetic dissimilarity analysis demonstrated the possibility to establish promising crosses.

\section{ACKNOWLEDGEMENTS}

To the National Science and Technology Institute (INCT-Café), to the Coffee Research Consortium, to the Bank of Northeast and the Research Support Foundation of the State of Minas Gerais (Fapemig) for financial support for the project, and to the owner of the Surubim Farm for making the experimental area available. To the fellowship of research productivity (PQ) granted by the National Council for Scientific and Technological Development (CNPq) and Fapemig.

\section{REFERENCES}

Antunes Filho H and Carvalho A (1954) Melhoramento do cafeeiro, ocorrência de lojas vazias em frutos de café Mundo Novo. Bragantia 13: $165-179$.

Barili LD, Vale NM, Prado AL, Carneiro JES, Silva FF and Nascimento M (2015) Genotype-environment interaction in common bean cultivars with carioca grain, recommended for cultivation in Brazil in the last 40 years. Crop Breeding and Applied Biotechnology 15: 244-250.

Carias CMOM, Tomaz MA, Ferrão MAG, Fonseca AFA, Ferrão RG and Gonçalves LSA (2014) Produtividade de grãos de cafeeiro conilon de diferentes grupos de maturação pelo procedimento REML/BLUP. Semina: Ciências Agrárias 35: 707-718.

Carvalho AM, Mendes ANG, Carvalho GR, Botelho CE, Gonçalves FMA and Ferreira AD (2010) Correlação entre crescimento e produtividade de cultivares de café em diferentes regiões de Minas Gerais, Brasil. Pesquisa Agropecuária Brasileira 45: 269-275.

Cecon PR, Silva FFE, Ferreira A, Ferrão RG, Carneiro APS, Detmann E, Faria PN and Morais TSS (2008) Análise de medidas repetidas na avaliação de clones de café 'Conilon'. Pesquisa Agropecuária Brasileira 43: 1171-1176.

Cilas C, Montagnon C and Bar-hen A (2011) Yield stability in clones of Coffea canephora in the short and medium term: longitudinal data analyses and measures of stability over time. Tree Genetics \&
Genome 7: 421-429.

CONAB (2014) Acompanhamento da Safra Brasileira Café Safra 2014. Terceiro levantamento, set. 2014. Available at <http://www.conab. gov.br/OlalaCMS/uploads/arquivos/14_09_16_08_47_43_boletim_ setembro_2014.pdf> Accessed on Sep 22, 2014.

Contarato CC, Tomaz MA, Alves FR, Sobreira FM, Jesus Junior WC, Rabello LKC, Ferrão MAG and Ferrão RG (2014) Reaction of cultivar coffee 'Vitória INCAPER 8142' of cornillon to parasitism of Meloidogyne exigua. Idesia 32: 93-97.

Cruz CD (2013) Genes: a software package for analysis in experimental statistics and quantitative genetics. Acta Scientiarum Agronomy 35: 271-276.

Ferrão RG, Fonseca AFA, Ferrão MAG, Bragança SM, Verdin Filho AC and Volpi PS (2007) Cultivares de café Conilon. In Ferrão RG, Fonseca AFA, Bragança SM, Ferrão MAG and Muner LH (eds) Café Conilon. INCAPER, Vitória, p. 205-225.

Ferrão RG, Cruz CD, Ferreira A, Cecon PR, Ferrão MAG, Fonseca AFA, Carneiro PCS and Silva MF (2008) Parâmetros genéticos em café Conilon. Pesquisa Agropecuária Brasileira 43: 61-69.

Gichimu BM and Omondi CO (2010) Early performance of five newly developed lines of Arabica Coffee under varying environment and spacing in Kenya. Agriculture and Biology Journal of North America 1: 32-39. 
Adaptability, stability, and genetic divergence of conilon coffee in Alto Suaçuí, Minas Gerais, Brazil

Guedes JM, Rezende JC, Lara JMRA, Carvalho SP, Pereira AA and Carvalho AM (2013) Genetic divergence among progenies resulting from the crossing of groups coffee timor hybrid and dilla \& alghe. Journal of Agricultural Science and Technology 3: 865-872.

Henderson CR (1984) Applications of linear models in animal breeding. University of Guelph, Ontario, 462p.

Ivoglo MG, Fazuoli LC, Oliveira ACB, Gallo PB, Mistro JC, Silvarolla MB and Toma-Braghini M (2008) Divergência genética entre progênies de cafés robustas. Bragantia 67: 823-831.

MAPA - Ministério da Agricultura, Pecuária e Abastecimento (2003) Instrução Normativa n. 8, 11 de junho de 2003. Available at <http:www.abic.com.br/arquivos/abic_nm_a1d_inst_normativa08. pdf $>$ Accessed on Mar 03, 2015.

Martinez HEP, Augusto HS, Cruz CD, Pedrosa AW and Sampaio NF (2007) Crescimento vegetativo de cultivares de café (Coffea arabica L.) e sua correlação com a produção em espaçamentos adensados. Acta Scientiarum Agronomy 29: 481-489.

Mistro JC, Fazuoli LC, Guerreiro Filho O, Silvarolla MB and Braghini MT (2008) Determination of the number of years in Arabic coffee progenies selection through repeatability. Crop Breeding and Applied Biotechnology 8: 79-84.

Mistro JC, Fazuoli LC, Gallo PB, Oliveira ACB, Braghini MT and Silvarolla MB (2007) Estimates of genetic parameters in Arabic coffee derived from Timor hybrid. Crop Breeding and Applied Biotechnology 7: 141-147.

Negreiros JRS, Andrade Neto RC, Miqueloni DP and Lessa LS (2014) Estimativa de repetibilidade para caracteres de qualidade de frutos de laranjeira-doce. Pesquisa Agropecuária Brasileira 49: 40-48.
Resende MDV (2007a) Matemática e estatística na análise de experimentos e no melhoramento genético. Embrapa Florestas, Colombo, 561p.

Resende MDV (2007b) Software SELEGEN - REML/BLUP: Sistema estatistico e seleção computadorizada via modelos lineares mistos. Embrapa Florestas, Colombo, 359p.

Resende MDV (2016) Software Selegen-REML/BLUP: a useful tool for plant breeding. Crop Breeding and Applied Biotechnology 16: 330-339.

Resende MDV and Duarte JB (2007) Precisão e controle de qualidade em experimentos de avaliação de cultivares. Pesquisa Agropecuária Tropical 37: 182-194.

Rodrigues WN, Tomaz MA, Ferrão RG, Ferrão MAG, Fonseca AFA and Miranda FD (2012) Estimativa de parâmetros genéticos de grupos de clones de café conilon. Coffee Science 7: 177-186.

Rosado AM, Rosado TB, Alves AA, Laviola BG and Bhering LL (2012) Seleção simultânea de clones de eucalipto de acordo com produtividade, estabilidade e adaptabilidade. Pesquisa Agropecuária Brasileira 47: 964-971.

Silva FL, Baffa DCF, Rezende JC, Oliveira ACB, Pereira AA and Cruz CD (2015) Variabilidade genética entre genótipos de café robusta no estado de Minas Gerais. Coffee Science 10: 20-27.

Silva FL, Barbosa MHP, Resende MDV, Peternelli LA and Pedrozo CA (2015) Efficiency of selection within sugarcane families via simulated individual BLUP. Crop Breeding and Applied Biotechnology 15: 1-9.

Teixeira AL, Souza FF, Pereira AA, Oliveira ACB and Rocha RB (2013) Performance of arabica coffee cultivars under high temperature conditions. African Journal of Agricultural Research 8: 4402-4407. 